\title{
SCHOOL EMPOWERMENT AS AN ENVIRONMENT LEARNING RESOURCE THROUGH WASTE MANAGEMENT TO ACHIEVE SUSTAINABLE DEVELOPMENT GOAL 12 (SDG'S): RESPONSIBLE CONSUMPTION AND PRODUCTION
}

\author{
Martini and Windarto \\ Universitas Budi Luhur, Indonesia. \\ martini@budiluhur.ac.id
}

\begin{abstract}
The deteriorating of environmental conditions nowadays is the environmental quality degradation impact caused by human activities that do not consider continuity and environmental sustainability. Therefore, human quality becomes a major issue and has an important role in the efforts of saving the environment. Competences in the field of knowledge, skill and attitude about the environmental issues is necessarily need by a whole of life in order to take a part in the efforts of conservation. School empowerment as an environmental learning resource through waste management is one of the efforts that could be gave to the students to increase environmental awareness. Learning resources are resources that can be utilize for the sake of teaching and learning process, either directly or indirectly, in parts or in whole. Environmental education is an educational program to foster students to have a rational understanding, awareness, attitude, and behavior that is responsible for the nature of sustainable development. Through these efforts, it is to be expect to create a clean, beautiful, comfortable, healthy and unobtrusive school environment and the whole of school society behavior who are more concerned about the environment. They are not only knowing it but also be able to apply it in daily life. The main activities aimed to embody the school as an environmental learning educational resource.
\end{abstract}

Keywords: SDGs, Recycle, Reduce, Reuse, Waste Management, Creative Product.

\section{INTRODUCTION}

Human quality becomes a major issue and has an important role in an environmental rescuing efforts. Competences in the field of knowledge, skills and attitudes about the environment is indispensable to all walks of life in the efforts of saving the environment. School empowerment as an environmental learning resource through waste management is one of the efforts which can be given to the students to increase environmental awareness. Through these efforts, it is to be expected to create a clean, beautiful, comfortable, healthy and unobtrusive school environment and the whole of school society behavior who are more concerned about the environment.

Schools have a strategic position in fostering environmental insight and foster the awareness of young generation in order to behave expediently to the environment. The natural resources saving and environmental friendly culture cannot grow up by itself without any habituation efforts since childhood. School management, which designed as a natural laboratory, will be an effective learning mode to establish that culture.

Schools have been potentially produce pollution and wasting of natural resources, for example: teaching and learning activities, administrative activities, etc. Workshop / laboratory activities, eating / drinking activities, vehicles usage, electricity / air conditioner usage, water usage, urine and human waste shelter, will generates: air, water, and soil pollution, waste, and electrical energy wastage.

By taking care of the environment as a paradigm, ethics, and life behavior to the school society, whole activities will always pay attention to the individual health and the surrounding environment. Thus, will be creates a clean, a beautiful, a comfortable and a healthy environment which can turns into the worth quality of living environment to human life and other living creatures. This is can stimulate the school society and guests feeling comfort at school and give the community an awareness of taking care and responsibility in creating a beautiful and healthy environment. To empowering schools as an environmental learning resource can be done by environmental greening, physical building maintenance, waste management, and the application of occupational health and work safety.

Through these activities a whole of school community (especially the students) will be able to obtain environmental education as a knowledge and skills to apply it in a cultural behavior. They are not only know but also be able to apply it in a a daily life. The main activities aimed to embody the school as an environmental learning educational resource.

The success of this effort is determined by the strong desire and determination a whole of school's community to preserve the environment. We hope that all schools can show its building safe, cool, shady, beautiful, comfortable, healthy and unobtrusive to its environment and the community's behavior cares about the 
environment. By the realization of the students who care about the environment hopefully makes an impact and accumulate synergistically among the future generations to keep the environment safe.

\section{PROBLEMS}

Pusat Kegiatan Belajar Masyarakat PKBM Negeri 27 (State Community Learning Center 27) Petukangan Jakarta is one of community learning centers in Jakarta that always committed to provide various trainings to increase their students skills and capacities. According to regulation of the Minister of Environment and Forestry No. 5 year 2013, article number 1 mentions that the Adiwiyata School Program is a program to embodied the school that cares and environmentally cultured. The Adiwiyata Program is implemented based on educative, participatory, and sustainable principles. Based on these three principles, there are four components of the Adiwiyata Program which include: (a) The environmental aspects of school policies; (b) Environmental-based school curriculum aspects; (c) Aspects of participatory-based school activities; and (d) the management aspects of school support facilities and infrastructures that are environmentally friendly. School's waste management based on zero waste concept is a school's priority due to it wants to teach the students about the $3 \mathrm{R}$ principle: Reduce, Reuse, Recycle. One thing that is currently still being a problem is the inorganic garbage deposits especially plastic waste that is quite annoying because it has not found the right handling solution. Limited resource on knowledge and skills to utilize appropriate technology being a constraint of the school.

\section{OUTPUTS}

This community service activity is aimed to create a school society that cares and is environmentally cultured by:

1. Creates a better conditions for school as a place for schools society (teachers, students, parents, etc) to learn and more aware to preserve the environment.

2. Encourage and assisting schools to participate in the Government's goals to preserve and develop the environment sustainably for the sake of the next generations.

3. The school society is also responsible for environmental saving efforts and the sustainable development.

An output of this community service activity is to increase the community's capacity by construct a recycling clinic which provides these activities:

a. Garbage Education

Provide counseling to the community to be able to separate organic waste, non-organic waste, and paper waste at home. Then educate the community to collect non-organic waste such as sachet beverage wrap, instant noodle wrap, cooking oil wrap, and so forth to be managed into creative products which has an economic values.

b. Education of Non-Organic Waste Processing

Provide trainings to process non-organic waste to be reusable goods such as creative products which has an economic values. The result can be re-used by the community itself, and also can be sold to the outside community as it is an economic value added for the community itself.

To support the entire activities, mentoring the community by giving a training of a non-organic waste processing into creative products which has an economic value for the community, as well as mentoring the community by giving an entrepreneurship education as a marketing strategy to sell the creative products which will be given within 5 days in the State Community Learning Center 27 Petukangan.

\section{APPROACHMENT METHOD}

An output that will be given to the counterpart and the targeted society is the management of non-organic waste into recycled creative products which has economic values. This aim can be achieved by construct a garbage recycling clinic at the Community Learning Center (PKBM Negeri 27) Petukangan. The approach is by providing a training to the society in the recycling clinic. The Training of Trainer (TOT) method will be used to reach the goal, which is by delivering lectures and then practicing immediately after. The educational activities are delivered by conducting an education of household plastic waste. Provides training to process the nonorganic waste into reusable goods and recycling of non-organic waste to be re-used by the society itself or can be sold to the outside of society.

\section{IMPLEMENTATION METHOD}

There are some steps to implement the method on this community service activity in the State Community Learning Center (PKBM) 27 Petukangan: 


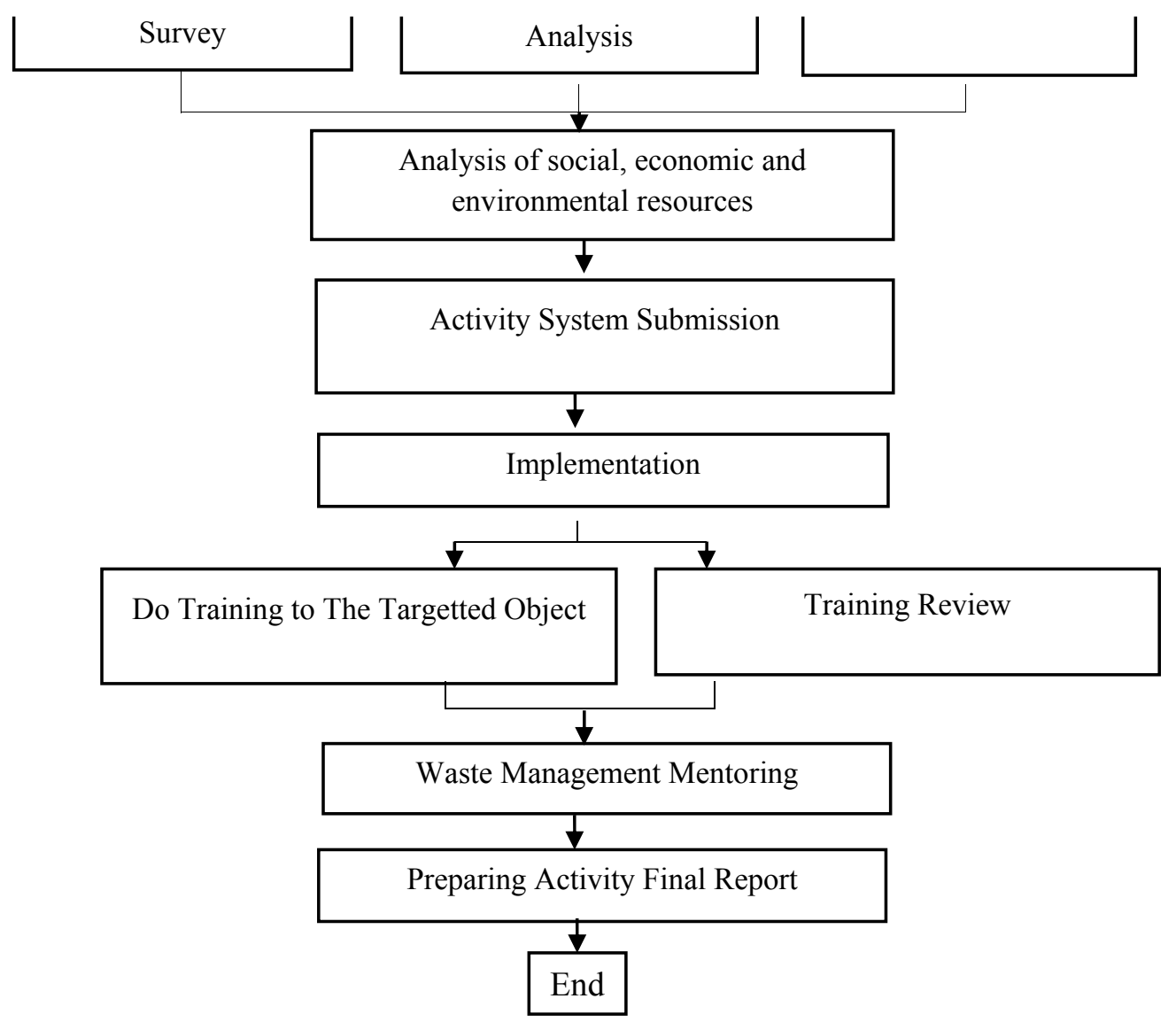

Picture 1 The Activity Proposed Steps

\section{[VITY EXECUTION}

'School Empowerment as an Environment Learning Resource Through Waste Management to Achieve nable Development Goal 12 (SDG's): Responsible Consumption and Production" activity has been held on it 3th 2019 at 08.00 WIB - 17.00 WIB in Taman Kupu-Kupu Universitas Budi Luhur Jakarta.

articipants involved in this activity consisted of 26 students, as well as 2 persons of counterpart from the 1 Negeri (State Community Learning Centre) 27 Petukangan.

to embody the "School Empowerment as an Environment Learning Resource Through Waste Management lieve Sustainable Development Goal 12 (SDG's): Responsible Consumption and Production" activity from ginning to the final are:

$\mathrm{n}$ the early stages is requesting permission to carry out the activity

) Collecting information about the problems faced by the partner.

:) requesting permission to PKBM Negeri (State Community Learning Center) 27 Petukangan to carry out the activity.

tt the activity implementation stage.

) provide consumption while the healthy environment training's held, learn how to recycling waste, as well as business training from recycled waste.

:) Provide a product sample of recycled garbage.

i) Provide work equipment to recycling products from non-organic waste. 


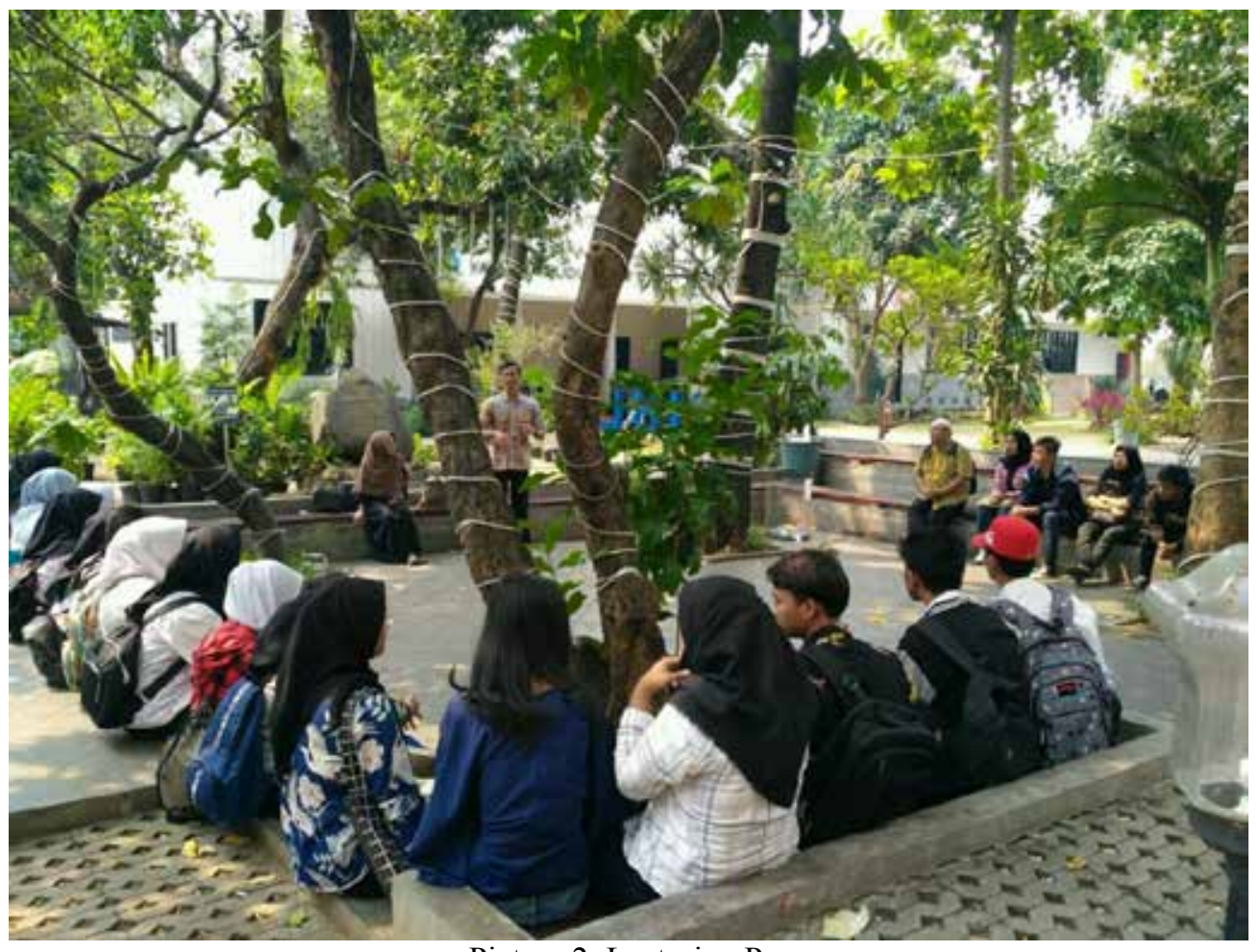

Picture 2: Lecturing Process

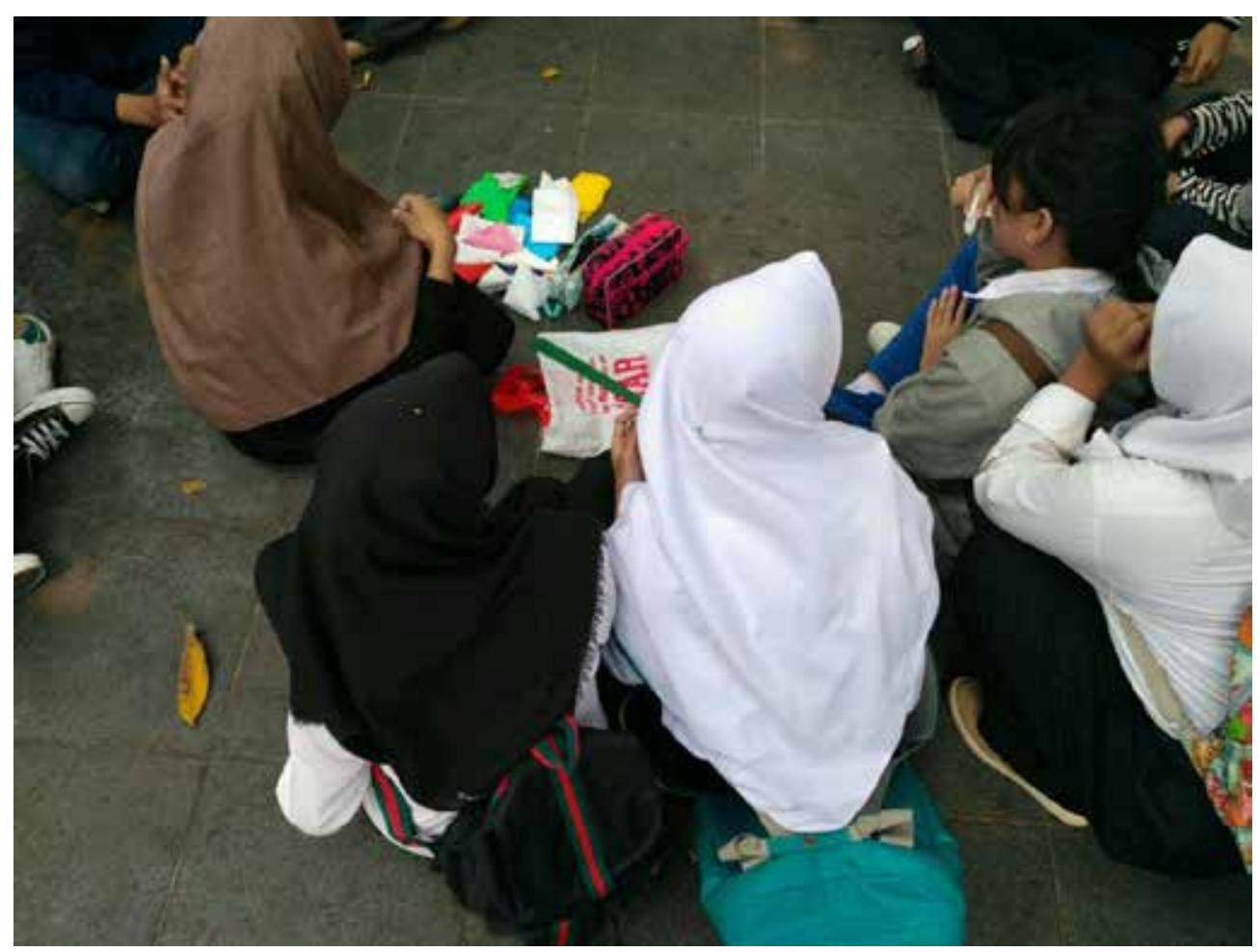

Picture 3 : Collecting Plactic Waste 

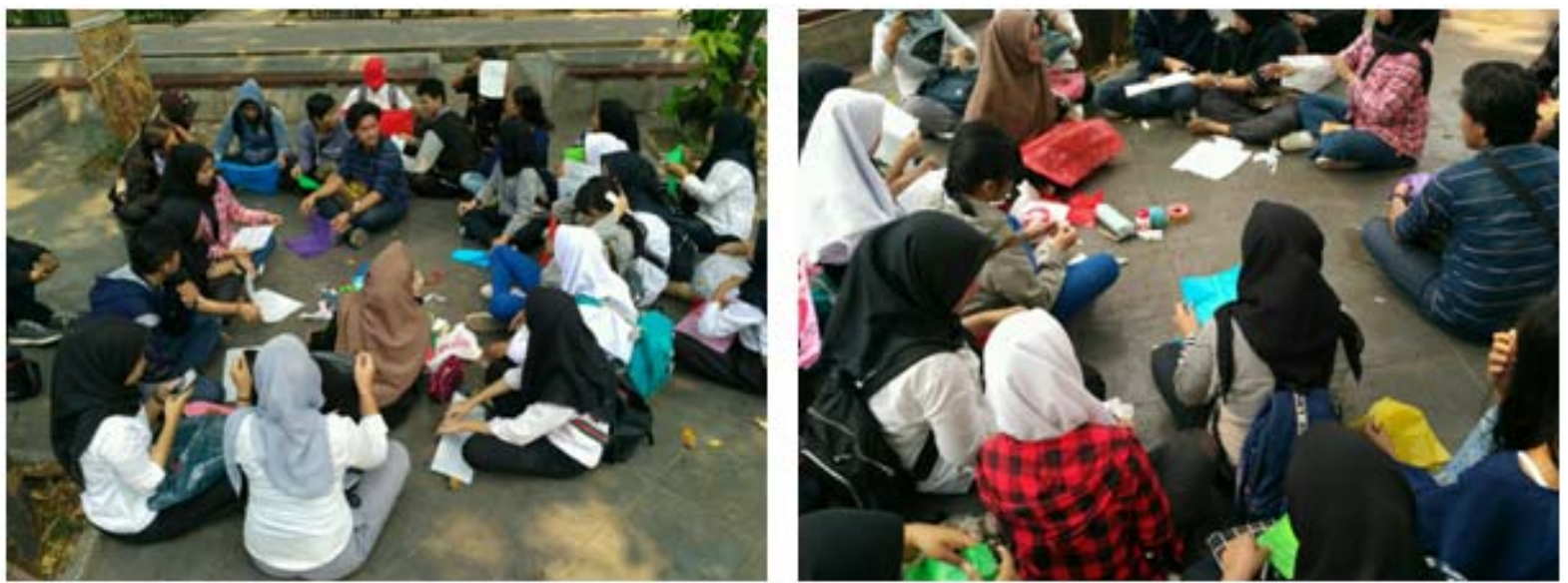

Picture 4 : Processing the Plactic Waste

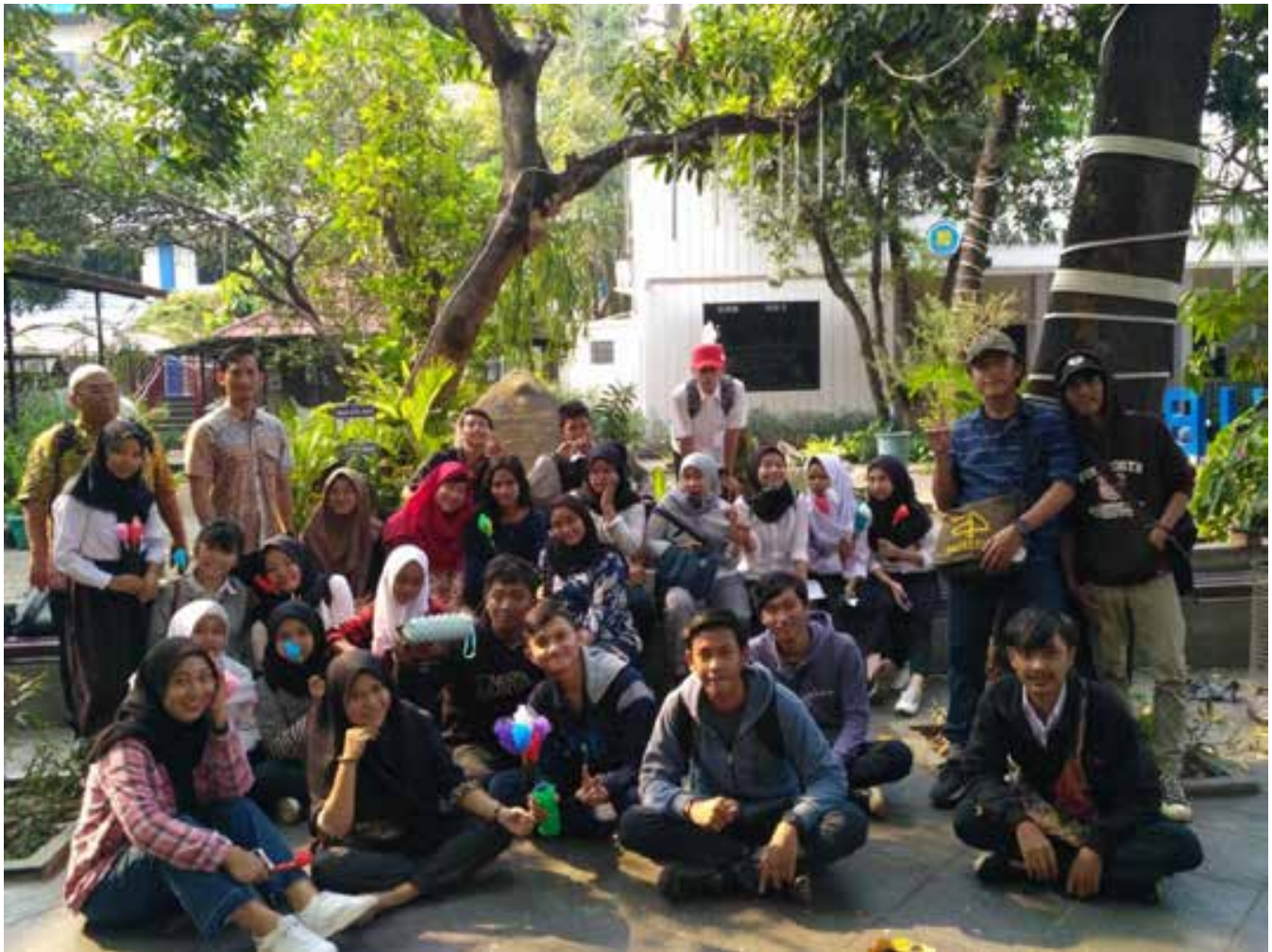

Picture 5 : Taking Picture Together with the Re-Used Plastic Waste Products

c. In the final stage is do reporting the activity results.

Do reporting the final activity reports and assisting partner to monitor the sustainability of the program become an independent and empowered community to be able to manage waste well. 


\section{CONCLUSION}

This community service activity is carried out as a real act of Universitas Budi Luhur to introduce a wider environmental love program that is garbage friendly, which aim to be achieved is relevant to Sustainable Development Goals 12 (SDG's) that is responsible and consumption production. One of ways to achieve this goal is by reusing some things that are generally rated as garbage into creative products.

Moreover, this activity is also benefit to reduce the impact caused by the waste deposits. Whether it is waste or garbage produced around the PKBM Negeri 27 or around South Jakarta, especially around Petukangan which can causing slum and unhealthy in the surrounding area. This activity also shows that to achieve the goal, cooperation between parties, including collaboration inter-fields of studies in this case between economic and business and information technology.

\section{REFERENCES}

Anggraeni Dyah, Sri Kurniasih, Putri Suryandari, IBM Menuju Kampung Recycle di Petukangan Utara, Laporan PPM 201

AS Danur, Ida (2005). Seminar Nasional : Pembangunan Lingkungan Perkotaan di Indonesia. Jakarta.

Blower, Andrew (1993).Planning for a Sustainable Environment : A Report by Town and Country Planning Association. Earthscan Publication. London.

Diningrat, Rendy A; "Bekerjasama Memperbaiki Kampung Kumuh"; URB.IM

Graham, Peter (2002). Building Ecology : First Principle for a Sustainable Built Environment. Blackwell. Science.

"Jokowi Benahi 360 Area Kumuh dalam Lima Tahun"; www.tempo.co

Leitman, Josef (1999). Sustaining Cities : Environmental Planning and Management in Urban Design. McgrawHill. New York, San Fransisco, Washington DC, Auckland, Bogota, Caracas, Lisbon, London, Madrid, Mexico City, Milan, Montreal, New Delhi, San Juan, Singapore, Sydney, Tokyo, Toronto.

M. Wheeler (2004). Planning for Sustainability : Creating Livable, Equitable, and Ecological Communities. Routledge.London and New York.

Nasution, S (2003). Metode Penelitian Naturalistik Kualitatif. Penerbit Tarsito. Bandung.

Sugandi, Aca (2007). Keynote Speaker Seminar : Perencanaan Pembangunan Perumahan dan Pemukiman Berwawasan Lingkungan dan Berkelanjutan. Jakarta.

Siahaan, Uras (2006). Seminar Nasional :Green Architecture in The Tropics. Jakarta.

Yeang, Ken (1995).Designing With Nature : The Ecological Basic for Architectural Design. Mcgraw- Hill. New York, San Fransisco, Washington DC, Auckland, Bogota, Caracas, Lisbon, London, Madrid, Mexico City, Milan, Montreal, New Delhi, San Juan, Singapore, Sydney, Tokyo, Toronto.
Kebijakan
Kota
Tasikmalaya
Mengenai
Pengelolaan

Sampah.<https://www.scribd.com/doc/226082026/Kebijakan-Kota-Tasikmalaya-Mengenai-

Pengelolaan-Sampah\#>.diakses pada 15 Oktober 2019. 